Tropical Journal of Pharmaceutical Research November 2017; 16 (11): 2601-2610

ISSN: $1596-5996$ (print); 1596-9827 (electronic)

(c) Pharmacotherapy Group, Faculty of Pharmacy, University of Benin, Benin City, 300001 Nigeria.

All rights reserved.

Available online at http://www.tjpr.org

Original Research Article

http://dx.doi.org/10.4314/tjpr.v16i11.5

\title{
Antioxidant, hypoglycemic and anti-diabetic activities of Ziziphus spina-christi (L) Willd (Rhamnacae) leaf extract
}

\author{
Amal AM Al-Ghamdi ${ }^{1}$ and Abdelaaty A Shahat ${ }^{2,3}$ \\ ${ }^{1}$ Department of Botany, Environment Program, Faculty of Biological Science, King Abdulaziz University, PO Box 35009, Jeddah \\ 21488, ${ }^{2}$ Pharmacognosy Department, College of Pharmacy, King Saud University, PO Box 2457, Riyadh 11451, Saudi Arabia, \\ ${ }^{3}$ Phytochemisrty Department, National Research Centre, 33 El Bohouth St, PO Box 12622, Dokki, Giza, Egypt
}

*For correspondence: Email: ashahat@ksu.edu.sa, aashahat@hotmail.com

Sent for review: 22 June 2017

Revised accepted: 10 October 2017

\begin{abstract}
Purpose: To investigate the antioxidant, hypoglycemic and antidiabetic activities as well as the phenolic composition of Ziziphus spina-christi (ZSC)

Methods: Eighty percent methanol extract (ZSC-1), as well as ethyl acetate (ZSC-2), n-butanol (ZSC-3) and aqueous (ZSC-4) fractions were administered orally to mice at doses of 250 and $500 \mathrm{mg} / \mathrm{kg}$ of body weight. The hypoglycemic and anti-diabetic activities of these fractions in the treated mice were evaluated after 7 and 15 days, using glibenclamide as a standard. Antioxidant activities in vitro were determined using stable free radical DPPH and ABTS radical scavenging techniques.

Results: The strongest ( $p<0.001)$ anti-diabetic activity $(25.59$ and $39.48 \%$ after 7 and 15 days, respectively) was found following treatment with $500 \mathrm{mg} / \mathrm{kg} Z S C$-3 fraction. Similarly, the highest $(p>$ $0.001)$ hypoglycemic effect was achieved with $500 \mathrm{mg} / \mathrm{kg} \mathrm{ZSC-3}$ treatment $(29.07$ and $35.56 \%$ after 7 and 15 days, respectively). ZSC-1 possessed the highest content of total flavonoids (36.2 $\mathrm{mg} / \mathrm{g})$ and total polyphenol $(82.3 \mathrm{mg} / \mathrm{g})$.

Conclusion: Fraction ZSC-3 displayed potential hypoglycemic activity while ZSC-1, ZSC-2 and ZSC-3 possess remarkable DPPH scavenging ability equivalent to 89,96 and $80.3 \%$ of the activity of the standard drug respectively.
\end{abstract}

Keywords: Ziziphus spina, Rhamnaceae, Hypoglycemic, Anti-diabetic, Flavonoids, Polyphenol

Tropical Journal of Pharmaceutical Research is indexed by Science Citation Index (SciSearch), Scopus, International Pharmaceutical Abstract, Chemical Abstracts, Embase, Index Copernicus, EBSCO, African Index Medicus, JournalSeek, Journal Citation Reports/Science Edition, Directory of Open Access Journals (DOAJ), African Journal Online, Bioline International, Open-J-Gate and Pharmacy Abstracts

\section{INTRODUCTION}

Diabetes mellitus, a metabolic disorder, causes damage to the heart, blood vessels, nerves, kidney and eyes. The disease may be inherited result from a deficiency of insulin production by pancreases and is also related to ineffective insulin production. Within the next 25 years, diabetes is projected to be one of the major causes of death throughout the world. As the current effective oral therapy for the treatment of diabetes causes side effects, new alternatives are required [1].
In modern world, medicinal plants are used to treat many diseases, every year, a large numbers of novel natural product are isolated with efficacy against various diseases. Therefore medicinal plants are a potential source of therapeutic agents [2]. In this study plants we assessed the potential of Zizyphus spina-christi which belong to Genus Zizyphus and family Rhamnaceae. Ziziphus species are a group of small trees that grow in many regions of the world. They belong to but are native to subtropical and temperate regions. 
More than forty Ziziphus species are distributed widely throughout the Mediterranean, Africa, Asia, and tropical America [3]. Ziziphus spinachristi has grown wild in the southern and western regions of the Kingdom of Saudi Arabia for many years, but its cultivation has been expanded, particularly into the central region of the Kingdom. The Arabic name of the plant is Sidr or Nabag, and it is used for various medicinal purposes. Species of this genus are used traditionally for the treatment of various diseases such as fever, insomnia, skin infections, urinary problems, digestives disorders, obesity, liver complaints and diabetes [4].

A clinical study of three species of this genus Ziziphus spina-christi, Zizyphus jojoba, and Zizyphus vulgaris revealed a great effect on insulin secretion. A literature survey revealed that a number of terpenoids, flavonoids, isoquinoline alkaloids, cyclopeptide, and glycosidic terpenes are found in various quantities in almost all Ziziphus species. The leaves of the plants in that genus contain ceanothic and betulic acids, different saponins and flavonoids, triterpenoids [5]. Pharmacological screening studies of different crude extracts of Zizyphus spina Christi showed antidiarrheal [6], central depressant effect and antinociceptive effect. Phenolic compounds can also act as antioxidants through the chelation of metal ions, the preventing of radical formation and the improving of the antioxidant endogenous system [7].

Different extracts and fractions from different parts of the plants showed bactericidal and antiviral activities against different microorganism [3]. In the current investigation, we aimed to evaluate the composition of the flavonoid and polyphenolic compounds in addition to the antioxidant and the anti-diabetic activities of the extract and various fractions of $Z S C$.

\section{EXPERIMENTAL}

\section{Plant material}

The leaves of Ziziphus spina-christi were collected from Mecca Road, Jeddah, Saudi Arabia in April 2016. The plant was authenticated by Prof Kadry Abdelkhalik, Umm Al-Qura University, Faculty of Science, Biology Department, Meccah, Saudi Arabia. A voucher specimen (no. Sh-Am-2016) has been kept in the herbarium of phytochemistry Department

\section{Chemicals}

Methanol, $n$-hexane, chloroform, butanol and ethyl acetate were analytical or HPLC grade.
Folin-Ciocalteu reagent; butylated hydroxylanisole (BHA); quercetin; and gallic acid were obtained from Sigma-Aldrich (Germany). Streptozotocin and glibenclamide were purchased from Sigma (USA) and Spimaco (Saudi Arabia) respectively. Other kits used for analysis of lipid analysis were purchased from local suppliers.

\section{Extract preparation}

The aqueous methanol extract (ZSC-1) was obtained by extraction of $1 \mathrm{~kg}$ of dried leaf powder in $4 \mathrm{~L} 80 \%(\mathrm{v} / \mathrm{v})$ methanol at $25-30^{\circ} \mathrm{C}$ for four days. The filtrate was collected. The combined filtrates were concentrated at $45 \stackrel{\circ}{\circ} \mathrm{C}$ under reduced pressure, using a rotary evaporator. To prepare fractions with solvents of different polarities, the concentrated aqueous solution was defatted with hexane and partitioned by solvent extraction using ethyl acetate (ZSC-2), and n-butanol (ZSC-3). The organic fractions and the residual aqueous fractions (ZSC-4) were concentrated separately.

\section{Animals}

Swiss albino mice male (20-25 g) of approximately the same age were obtained from the Experimental of the Animal Care Center, Faculty of Pharmacy, University of King Saud, Riyadh, and maintained in controlled conditions (temperature, $22 \pm 2^{\circ} \mathrm{C}$; humidity, $55 \% ; 12: 12$ $\mathrm{h}$ light-dark cycle). The mice were provided with Purina chow and free access to drinking water. Before use, the mice were acclimatized to the experimental conditions for 7 days. The study was approved (clearance no. CBR-4538) by Research Ethics Committee of Experimental Animal Care Society, College of Pharmacy, King Saud University (Riyadh, Saudi Arabia), and followed the recommendations of the National Institutes of Health Guide for Care and Use of Laboratory Animals [8]

\section{Induction of streptozotocin-induced diabetes}

Diabetes was induced by injecting $60 \mathrm{mg} / \mathrm{kg}$ body weight streptozotocin (STZ) in $0.1 \mathrm{M}$ cold citrate buffer $(\mathrm{pH}=4.5)$ intraperitoneally. Diabetes was confirmed by determining fasting blood glucose concentration [9]. The mice were divided into six groups of six mice each. Groups I and II included untreated diabetic control mice and diabetic mice administrated standard (10 $\mathrm{mg} / \mathrm{kg} /$ day glibenclamide). Group III, IV, V and VI were treated with extracts at the dose level of $250 \mathrm{mg} / \mathrm{kg}$ and $500 \mathrm{mg} / \mathrm{kg}$ respectively, for 15 days. Finally, on day 15, blood was collected for 
hematological and biochemical parameters. Body weight and blood glucose level (with the help of Gluco Check) were measured weekly on overnight-fasted animals. At the end of the experimental period, the animals were fasted overnight, blood $(0.2 \mathrm{~mL})$ was collected for various biochemical analyses, and the animals were sacrificed by cervical decapitation.

\section{Evaluation of hypoglycemic and anti-diabetic activities}

The drugs were administrated at doses of 250 and $500 \mathrm{mg} / \mathrm{kg}$ body weight to each animal. Tween $80(1 \mathrm{~mL})$ was added as a solvent to each extract/fraction. The experiment was conducted in accordance with a previously reported procedure [10]. Briefly, for hypoglycemic evaluation, six groups of animals were prepared with six mice in each group. Group I was administrated normal saline (the diabetic control), group II was administered $5 \mathrm{mg} / \mathrm{kg}$ glibenclamide (standard drug) and groups III, IV, V and VI were administered the test extracts or fractions at 250 and $500 \mathrm{mg} / \mathrm{kg}$ body weight.

The extracts, fractions and drugs were orally administrated to animals after fasting for $24 \mathrm{~h}$. Blood samples were collected before administered (zero time) and at 30,60, 90 and 120 min after the drugs administered and blood glucose level was measured using Reflotron ${ }^{\circledR}$ instrument. For anti-diabetic screening, diabetes was induced in the overnight fasted animals by intraperitoneal injection of $150 \mathrm{mg} / \mathrm{kg}$ ). The induction of diabetes was completed $72 \mathrm{~h}$ after injection; thereafter the experiment proceeded as described for the hypoglycemic experiment.

\section{Glucose tolerance test}

All mice were fasted before the experiment. Group 1, the diabetic control, was administrated $1 \mathrm{~mL}$ normal saline, group 2 was administered 1 $\mathrm{mg} / \mathrm{kg}$ glibenclamide, and the other groups were administered ZSC-1, ZSC-2 and ZSC-3 at 250 and $500 \mathrm{mg} / \mathrm{kg}$, respectively. The animals were loaded with glucose $(3 \mathrm{~g} / \mathrm{kg})$ [11] and blood samples were collected immediately before drug administration and at 30, 60, 90 and $120 \mathrm{~min}$ after drug administration.

The serum glucose level was immediately specified by using a glucose estimation kit Refretron (Roche, Germany) to detect the hypoglycemic effects of the tested samples compared to the effects of the test samples compared to the effects of the standard group and control.

\section{Evaluation of biochemical parameters}

Triglycerides (TG), cholesterol, lipoprotein high density (HDL-C), very low density lipoprotein (VLDL-C) and low density lipoprotein (LDL-C) were calculated by using Refretron diagnostic kit (Roche, Germany).

\section{Determination of total flavonoids}

The total content of flavonoids was measured using an $\mathrm{AlCl}_{3}$ colorimetric assay, based on the method of Zhang et al. [12], with quercetin as a reference compound. One milliliter of the sample was mixed with methanol extract solution containing $2 \% \mathrm{AlCl}_{3}$. The mixture was maintained at $30{ }^{\circ} \mathrm{C}$ for $15 \mathrm{~min}$ to allow the formation of a complex between the aluminum chloride and the flavonoids. The complex was measured at $430 \mathrm{~nm}$ using an UV-Vis Spectrophotometer (UV-1650 PC, ShimadzuGermany). Quercetin concentrations from 00$100 \mathrm{mg} / \mathrm{L}$ were used to construct a calibration curve. Total flavonoid content (TFC) was expressed as qurcetin equivalent (QE) in $\mathrm{mg} / \mathrm{g}$ dry weight of plant extract.

\section{Assessment of total phenolic content}

The concentration of phenolic content was quantified in accordance with the method of Shahat et al. [13]. Fifty microliters of the test samples were mixed with $2 \mathrm{~mL}$ of $2 \%$ sodium carbonate and the mixture were maintained at 25 - $30{ }^{\circ} \mathrm{C}$ for $2 \mathrm{~min}$. After the addition of FolinCiocalteau reagent $(50 \%, 100 \mu \mathrm{L})$, the reaction was allowed to proceed for $30 \mathrm{~min}$ at room temperature, after which the absorbance was measured at $720 \mathrm{~nm}$. Gallic acid was used to construct a standard curve and the phenolic content present in the extract was expressed as gallic acid equivalents.

\section{Antioxidant activity}

\section{DPPH radical scavenging activity}

The effect of the extract, fractions and positive control (BHA) on DPPH scavenging free radical activity were determined based on the method described by Khalifa et al [14] with minor change. The stable free radical DPPH was dissolved in methanol to produce a $100 \mu \mathrm{M}$ solution. The DPPH solution $(3 \mathrm{~mL})$ was added to different concentration ranging from $20-100 \mu \mathrm{g} / \mathrm{mL}$ of the tested samples. One $\mathrm{ml}$ of methanol instead of the plant extract was used for control. After 30 min, the absorbance was measured at $520 \mathrm{~nm}$ and the DPPH inhibitory activities (D) was computed as in Eq 1. 
$\mathrm{D}(\%)=\mathrm{Ao}-(\mathrm{At} / \mathrm{Ao}) 100$

where $\mathrm{At}=$ absorbance of the extract, $\mathrm{A} 0=$ absorbance of control

\section{Determination of ABTS radical scavenging activity}

The radical scavenging activity of the total extract and different fractions of $Z S C$ and the positive control, BHA, were measured against the 2, 2azino-bis (3-ethylbenzo-thiazoline-6-sulfonic acid (ABTS) radical cation by using the method of Smeriglio et al and Shahat et al [15]. Aqueous solution of $2.45 \mathrm{mmol} / \mathrm{L}$ potassium persulfate and $7 \mathrm{mmol} / \mathrm{L}$ of ABTS in water were prepared. The two solutions were mixed in a $1: 1 \mathrm{v} / \mathrm{v}$ ratio and stored in the dark for $6 \mathrm{~h}$ at room temperature to allow production of the ABTS radical. The stock solution of ABTS was diluted with methanol. The tested samples were prepared at $5 \mathrm{mg} / \mathrm{mL}$. Serial dilutions of the tested samples were prepared and the volumes were adjusted to $1 \mathrm{~mL}$ using methanol. ABTS solution was added to different concentration of the test samples, mixed strongly and incubated at $30{ }^{\circ} \mathrm{C}$ for $20 \mathrm{~min}$. The absorbance of the solution was recorded at 700 $\mathrm{nm}$. The affinity of test samples to reaction with the ABTS free radical was calculated as in Eq 2.

$S(\%)=A o-(A t / A o) 100$

where S, Ao and At are radical scavenging activity, absorbance of control and absorbance test sample, respectively.

\section{Statistical analysis}

The data are expressed as mean \pm standard deviation (SD) and were statistically analyzed using the one-way analysis of variance (ANOVA) or Student's t-test, followed by Dunnett's multiple comparison test. Statistical significance was set at $p<0.05$, or $p<0.01$, or $p<0.001$

\section{RESULTS}

\section{Anti-diabetic activity}

The blood glucose level after treatment of fasted mice with 250 and $500 \mathrm{mg} / \mathrm{kg}$ body weight of tested fractions after 7 and 15 days are shown in Table 1. The anti-diabetic activities increased with an increase in the dose of all tested fractions. The highest results $25.59 \%$ (7 days) and $39.48 \%$ (15 days) were found after the administration of $500 \mathrm{mg} / \mathrm{kg}$ body weight ZSC-3 compared with standard drug. These tested frictions are further investigated for oral glucose tolerance test and the determination of different biochemical parameters.

\section{Hypoglycemic activity}

The effect of the different plant extracts at a dose of 250 and $500 \mathrm{mg} / \mathrm{kg}$ body weight on fasting blood sugar level were assessed in normal mice and the results are summarized in Table 2 . The highest decrease in glucose level found by ZSC3 at $500 \mathrm{mg} / \mathrm{kg}$ of body weight was $29.07 \%$ (7 days) and 35.56 (15 days) compared with standard drug. As shown in Table 2, a continuous increase can be observed, hypoglycemic activities increased with the increase in the dose of each friction from 250 to $500 \mathrm{mg} / \mathrm{kg}$ of body weight. The second highest decrees of $24.64 \%$ ( 7 days) and 34.85 (15 days) were found after treatment with $500 \mathrm{mg} / \mathrm{kg}$ of body weight of the ZSC-2 friction.

\section{Glucose tolerance}

The blood glucose level of mice administered 250 and $500 \mathrm{mg} / \mathrm{kg}$ of body weight of all tested fractions was investigated after 30,60, 90 and $120 \mathrm{~min}$. After the administration of the compounds, It was noted that the glucose level first increased between 30 to $60 \mathrm{~min}$ after administration and the decreased between 90 and $120 \mathrm{~min}$ as shown in Table 3.

\section{Biochemical profile}

The measurement of the other parameters such as cholesterol, triglyceride HDL, LDL and VLDL are presented in Table 4. Here, significant changes can be observed in the lipid profiles with the tested fraction at both dose levels. A very significant change in HDL (96.39\%) was found after ZSC-3 treatment and then after ZSC-2 $(71.28 \%)$. both at $500 \mathrm{mg} / \mathrm{kg}$ dose level. The result $(96.39 \%)$ was greater than that observed after treatment with the standard drug $(95.80 \%)$. Fraction ZSC-3 at dose level $500 \mathrm{mg} / \mathrm{kg}$ resulted in highest LDL (63.49\%) followed by ZSC-2 $(49.16 \%)$. The same fractions also showed the highest result for VLDL (29.31 and $24.72 \%$, respectively. At $500 \mathrm{mg} / \mathrm{kg}$ bodyweight, the two fractions ZSC-3 and ZSC-2 led to a significant percentage change in cholesterol and triglyceride levels.

Body weight was monitored throughout. After 15 days, significant change of body weight ( $p<$ 0.001 ) were evident after the administration of ZSC-2 $(500 \mathrm{mg} / \mathrm{kg})$ and both doses of ZSC-3 and ZSC-4 (Table 5). 
Table 1: Anti-diabetic activity of extracts on fasting blood glucose level in STZ-induced diabetic mice

\begin{tabular}{|c|c|c|c|c|c|c|}
\hline \multirow[b]{2}{*}{ Group } & \multirow{2}{*}{$\begin{array}{c}\text { Dose } \\
\text { (mg/kg) }\end{array}$} & \multirow{2}{*}{$\begin{array}{c}\text { Before } \\
\text { treatment } \\
\text { Day } 0 \text { (Mean } \pm \\
\text { S.E.) }\end{array}$} & \multicolumn{4}{|c|}{ Blood glucose concentration (mg/dL) after treatment) } \\
\hline & & & $\begin{array}{c}\text { day } 7 \\
\text { (Mean } \pm \text { S.E.) }\end{array}$ & $\%$ Change & $\begin{array}{c}\text { Day } 15^{\text {th }} \text { (Mean } \pm \\
\text { S.E.) }\end{array}$ & $\%$ Change \\
\hline $\begin{array}{l}\text { Group I } \\
\text { Diabetic control }\end{array}$ & & $307.50 \pm 6.41$ & $317.66 \pm 4.13$ & $3.30 \uparrow$ & $315.50 \pm 3.87$ & $2.60 \uparrow$ \\
\hline $\begin{array}{l}\text { Group II } \\
\text { Glibenclamide }\end{array}$ & 5 & $299.16 \pm 8.98$ & $158.83 \pm 7.80^{* * *}$ & $46.90 \downarrow$ & $153.00 \pm 3.19^{\star \star \star}$ & $48.85 \downarrow$ \\
\hline Group III (ZSC-1 & $\begin{array}{l}250 \\
500\end{array}$ & $\begin{array}{l}315.66 \pm 2.49 \\
326.00 \pm 9.70\end{array}$ & $\begin{array}{c}310.16 \pm 3.14 \\
296.66 \pm 4.70^{*}\end{array}$ & $\begin{array}{l}1.74 \downarrow \\
8.99 \downarrow\end{array}$ & $\begin{array}{l}302.50 \pm 3.56^{\star} \\
288.50 \pm 6.27^{\star}\end{array}$ & $\begin{array}{r}4.17 \downarrow \\
11.50 \downarrow\end{array}$ \\
\hline Group III (ZSC-2) & $\begin{array}{l}250 \\
500\end{array}$ & $\begin{array}{c}318.66 \pm 10.76 \\
305.33 \pm 7.68\end{array}$ & $\begin{array}{l}287.16 \pm 4.19^{\star} \\
271.83 \pm 3.33^{\star *}\end{array}$ & $\begin{array}{r}9.88 \downarrow \\
10.71 \downarrow\end{array}$ & $\begin{array}{l}277.16 \pm 6.06^{\star *} \\
201.66 \pm 3.92^{\star * *}\end{array}$ & $\begin{array}{l}13.02 \downarrow \\
33.95 \downarrow\end{array}$ \\
\hline Group III (ZSC-3) & $\begin{array}{l}250 \\
500\end{array}$ & $\begin{array}{l}316.83 \pm 11.63 \\
315.50 \pm 11.13\end{array}$ & $\begin{array}{c}276.00 \pm 4.28^{*} \\
234.00 \pm 5.83^{\star * *}\end{array}$ & $\begin{array}{l}12.88 \downarrow \\
25.59 \downarrow\end{array}$ & $\begin{array}{l}226.83 \pm 7.18^{\star \star *} \\
190.33 \pm 2.99^{\star \star *}\end{array}$ & $\begin{array}{l}28.40 \downarrow \\
39.48 \downarrow\end{array}$ \\
\hline Group III (ZSC-4) & $\begin{array}{l}250 \\
500\end{array}$ & $\begin{array}{l}326.00 \pm 12.29 \\
331.66 \pm 16.54\end{array}$ & $\begin{array}{l}299.83 \pm 4.58 \\
295.83 \pm 6.02 \\
\end{array}$ & $\begin{array}{c}8.02 \downarrow \\
10.80 \downarrow \\
\end{array}$ & $\begin{array}{l}290.33 \pm 11.03 \\
288.50 \pm 3.73^{*}\end{array}$ & $\begin{array}{l}10.94 \downarrow \\
13.01 \downarrow\end{array}$ \\
\hline
\end{tabular}

All values represent mean $\pm \mathrm{SEM} ;{ }^{\star} p<0.05 ;{ }^{\star *} p<0.01,{ }^{\star \star *} p<0.001$; ANOVA, followed by Dunnett's multiple comparison test

Table 2: Hypoglycemic effect of extracts on normal mice treated for two weeks

\begin{tabular}{|c|c|c|c|c|c|c|}
\hline \multirow[b]{2}{*}{ Group } & \multirow{2}{*}{$\begin{array}{l}\text { Dose } \\
(\mathrm{mg} / \mathrm{kg})\end{array}$} & \multirow{2}{*}{$\begin{array}{c}\begin{array}{c}\text { Before } \\
\text { treatment }\end{array} \\
\text { Day 0 } \\
\text { (mean } \pm S E)\end{array}$} & \multicolumn{4}{|c|}{ Blood glucose $(\mathrm{mg} / \mathrm{dl})$ post-treatment } \\
\hline & & & day 7 (mean $\pm S E)$ & $\%$ Change & $\begin{array}{c}\text { Day } 15^{\text {th }} \\
\text { (mean } \pm S E)\end{array}$ & $\%$ Change \\
\hline $\begin{array}{l}\text { Group I } \\
\text { Normal saline }\end{array}$ & & $109.50 \pm 1.70$ & $109.66 \pm 2.30$ & No change & $110.83 \pm 2.34$ & No change \\
\hline $\begin{array}{l}\text { Group II } \\
\text { Glibenclamide }\end{array}$ & 5 & $111.66 \pm 3.10$ & $62.75 \pm 2.50^{\star * *}$ & $43.80 \downarrow$ & $56.56 \pm 2.81^{\star \star *}$ & $49.34 \downarrow$ \\
\hline Group III (ZSC-1) & $\begin{array}{l}250 \\
500\end{array}$ & $\begin{array}{l}106.16 \pm 1.64 \\
112.33 \pm 2.70\end{array}$ & $\begin{array}{c}100.06 \pm 1.50^{*} \\
99.33 \pm 3.74^{*}\end{array}$ & $\begin{array}{c}5.74 \downarrow \\
11.57 \downarrow\end{array}$ & $\begin{array}{l}99.93 \pm 2.61^{*} \\
93.13 \pm 4.13^{* *}\end{array}$ & $\begin{array}{c}9.16 \downarrow \\
17.09 \downarrow\end{array}$ \\
\hline Group IV (ZSC-2) & $\begin{array}{l}250 \\
500\end{array}$ & $\begin{array}{l}109.33 \pm 2.26 \\
108.83 \pm 2.21\end{array}$ & $\begin{array}{l}87.91 \pm 2.41^{* \star *} \\
82.01 \pm 2.01^{\star \star \star}\end{array}$ & $\begin{array}{l}19.58 \downarrow \\
24.64 \downarrow\end{array}$ & $\begin{array}{l}79.38 \pm 2.45^{\star \star \star} \\
70.90 \pm 1.30^{\star \star \star}\end{array}$ & $\begin{array}{l}27.39 \downarrow \\
34.85 \downarrow\end{array}$ \\
\hline Group V (ZSC-3) & $\begin{array}{l}250 \\
500 \\
250\end{array}$ & $\begin{array}{l}102.33 \pm 3.26 \\
109.83 \pm 1.99 \\
107.00+3.11\end{array}$ & $\begin{array}{c}88.06 \pm 1.70^{\star *} \\
77.90 \pm 2.81^{\star * *} \\
108\end{array}$ & $\begin{array}{l}13.94 \downarrow \\
29.07 \downarrow\end{array}$ & $\begin{array}{l}83.00 \pm 1.61^{* * *} \\
70.76 \pm 2.21^{\text {*** }}\end{array}$ & $\begin{array}{c}18.89 \downarrow \\
35.56 \downarrow\end{array}$ \\
\hline Group VI (ZSC-4) & 500 & $107.83 \pm 1.79$ & $101.63 \pm 1.71^{*}$ & $5.74 \downarrow$ & $98.33 \pm 1.89^{\star \star}$ & $8.80 \downarrow$ \\
\hline
\end{tabular}

All values represent mean \pm SEM. ${ }^{*} p<0.05 ;{ }^{* *} p<0.01,{ }^{* * *} p<0.001$; ANOVA, followed by Dunnett's Multiple comparison tests

Table 3: Effect of extract fractions on oral glucose tolerance (OGT) in mice

\begin{tabular}{|c|c|c|c|c|c|c|}
\hline \multirow{2}{*}{ Group } & \multirow{2}{*}{$\begin{array}{l}\text { lose } \\
\text { (mg/kg) }\end{array}$} & \multirow{2}{*}{$\begin{array}{c}\text { Before } \\
\text { treatment } \\
(\mathrm{O} h)\end{array}$} & \multicolumn{4}{|c|}{ Blood glucose level post-treatment } \\
\hline & & & $30 \mathrm{~min}$ & $60 \min$ & $90 \min$ & 120 min \\
\hline Group I Normal saline & & $117.33 \pm 2.92$ & $298.33 \pm 5.18^{* * *}$ & $347.66 \pm 6.18^{* * *}$ & $249.66 \pm 6.40^{* * *}$ & $224.00 \pm 9.54^{* * *}$ \\
\hline Group II Glibenclamide & 5 & $115.50 \pm 3.55$ & $195.66 \pm 5.55^{\star * *}$ & $169.50 \pm 4.92^{\star \star \star}$ & $151.83 \pm 3.27^{\star * *}$ & $131.50 \pm 2.76^{\star *}$ \\
\hline \multirow{2}{*}{ Group III (ZSC-1) } & 250 & $112.00 \pm 2.89$ & $282.50 \pm 6.98^{\star * *}$ & $310.50 \pm 17.65^{\star * *}$ & $270.33 \pm 7.84^{\star * *}$ & $216.83 \pm 10.77^{\star \star \star}$ \\
\hline & 500 & $112.00 \pm 2.70$ & $298.83 \pm 5.24^{* * *}$ & $323.83 \pm 6.72^{\star \star *}$ & $234.33 \pm 7.33^{* * *}$ & $208.50 \pm 3.12^{* * *}$ \\
\hline \multirow{2}{*}{ Group IV (ZSC-2) } & 250 & $115.00 \pm 2.23$ & $289.33 \pm 6.40^{\star * *}$ & $314.00 \pm 7.35^{\star * *}$ & $213.16 \pm 5.53^{\star * *}$ & $199.00 \pm 5.05^{\star \star *}$ \\
\hline & 500 & $115.50 \pm 2.77$ & $289.50 \pm 5.50^{\star * *}$ & $339.83 \pm 6.28^{\star \star \star}$ & $189.16 \pm 6.06^{* * *}$ & $173.33 \pm 5.88^{* * *}$ \\
\hline \multirow{2}{*}{ Group V (ZSC-3) } & 250 & $117.33 \pm 3.92$ & $261.16 \pm 9.60^{* * *}$ & $317.83 \pm 5.36^{* * *}$ & $223.16 \pm 6.59^{\star * *}$ & $168.33 \pm 6.04^{\star * *}$ \\
\hline & 500 & $115.66 \pm 1.76$ & $178.16 \pm 7.73^{* * *}$ & $316.83 \pm 7.12^{* * *}$ & $180.66 \pm 7.73^{\star * *}$ & $153.00 \pm 4.15^{\star \star *}$ \\
\hline \multirow{2}{*}{ Group VI (ZSC-4) } & 250 & $118.83 \pm 3.10$ & $279.50 \pm 6.11^{\star * *}$ & $320.33 \pm 5.22^{\star \star *}$ & $283.00 \pm 6.56^{* * *}$ & $216.16 \pm 3.29^{\star * *}$ \\
\hline & 500 & $112.83 \pm 2.13$ & $294.16 \pm 4.52^{\star \star \star}$ & $324.66 \pm 5.32^{\star \star *}$ & $242.66 \pm 7.14^{\star * *}$ & $193.66 \pm 6.13^{* * *}$ \\
\hline
\end{tabular}

All values represent mean $\pm \mathrm{SEM} ;{ }^{* *} p<0.01,{ }^{* *} p<0.001$; ANOVA, followed by Dunnett's multiple comparison test

\section{Total flavonoids}

The total flavonoid content of the extract and fractions were measured by using the $\mathrm{AlCl}_{3}$ assay; the results are presented in Figure 1. The flavonoid content was highest in $80 \%$ methanol extract (ZSC-1, $36.2 \mathrm{mg} / \mathrm{g}$ ), followed by ethyl acetate (ZSC-1, $31.2 \mathrm{mg} / \mathrm{g}$ ), n-butanol (ZSC-3, $28.2 \mathrm{mg} / \mathrm{g}$ ), and the aqueous fraction (ZSC-4, $24.6 \mathrm{mg} / \mathrm{g}$ ). ZSC-1 showed the highest flavonoid content, followed by ZSC-2 and ZSC-3 extracts; ZSC-4 showed the lowest flavonoid content. 
Table 4: Effect of extract on lipid profile of STZ-induced diabetic mice

\begin{tabular}{|c|c|c|c|c|c|c|c|c|c|c|c|}
\hline \multirow[b]{2}{*}{ Group } & \multirow{2}{*}{$\begin{array}{c}\text { Dose } \\
(\mathrm{mg} / \mathrm{kg})\end{array}$} & \multicolumn{2}{|c|}{ Cholesterol (mg/dL) } & \multicolumn{2}{|c|}{ Triglycerides (mg/dL) } & \multicolumn{2}{|c|}{ HDL (mg/dL) } & \multicolumn{2}{|c|}{ LDL(mg/dL) } & \multicolumn{2}{|c|}{ VLDL (mg/dL) } \\
\hline & & Mean \pm SE & $\begin{array}{c}\% \\
\text { Change }\end{array}$ & Mean \pm SE & $\begin{array}{c}\% \\
\text { Change }\end{array}$ & Mean \pm SE & $\begin{array}{c}\% \\
\text { Change }\end{array}$ & Mean \pm SE & $\begin{array}{c}\% \\
\text { Change }\end{array}$ & Mean \pm SE & $\begin{array}{c}\% \\
\text { Change }\end{array}$ \\
\hline Normal saline & & $102.02 \pm 2.65$ & & $100.41 \pm 2.79$ & & $54.58 \pm 2.12$ & & $27.36 \pm 2.79$ & & $20.08 \pm 0.55$ & \\
\hline Gp I diabetic & & $209.83 \pm 4.41^{\mathrm{a}}$ & 105.65 & $193.33 \pm 3.15^{\star \star \star a}$ & 92.53 & $22.63 \pm 0.97^{* \star \star a}$ & 54.53 & $148.53 \pm 3.9^{* * * a}$ & 442.75 & $38.66 \pm 0.63^{* * \star a}$ & 92.53 \\
\hline Gp II glibenclamide & 5 & $120.66 \pm 3.56^{* * \star b}$ & 42.49 & $115.66 \pm 2.27^{\star * \star} b$ & 40.17 & $44.31 \pm 2.05^{\star \star \star \mathrm{b}}$ & 95.80 & $53.21 \pm 3.87^{\star \star \star b}$ & 64.17 & $23.13 \pm 0.45^{\star \star \star b}$ & 40.17 \\
\hline Gp III & 250 & $201.66 \pm 4.52$ & 3.89 & $183.83 \pm 5.15^{b}$ & 4.91 & $22.46 \pm 1.03^{\mathrm{b}}$ & & $142.43 \pm 4.6^{\mathrm{b}}$ & 4.10 & $36.76 \pm 1.03^{b}$ & 4.91 \\
\hline (ZSC-1) & 500 & $192.66 \pm 3.39 * \mathrm{D}$ & 8.18 & $179.16 \pm 4.54^{* \mathrm{D}}$ & 7.32 & $26.91 \pm 1.02^{* \mathrm{D}}$ & 18.92 & $129.91 \pm 3.8^{\star \star \mathrm{b}}$ & 12.53 & $35.83 \pm 0.98^{* \mathrm{D}}$ & 7.32 \\
\hline Group IV & 250 & $171.16 \pm 4.18^{* * \star \mathrm{D}}$ & 18.42 & $171.00 \pm 2.19^{* \star \star D}$ & 11.55 & $30.36 \pm 1.08^{\star \star \star D}$ & 34.16 & $106.6 \pm 4.45^{\star \star \star \mathrm{b}}$ & 28.23 & $34.20 \pm 0.43^{\star \star \star \mathrm{b}}$ & 11.55 \\
\hline (ZSC-2) & 500 & $143.33 \pm 2.34^{* * \star \mathrm{D}}$ & 31.69 & $145.33 \pm 2.45^{\star \star \star \mathrm{b}}$ & 24.82 & $38.76 \pm 1.09^{\star \star \star \mathrm{D}}$ & 71.28 & $75.5 \pm 3.02^{\star \star \star \triangleright}$ & 49.16 & $29.06 \pm 0.49^{\star \star \star D}$ & 24.72 \\
\hline Gp V & 250 & $157.66 \pm 4.36^{* * \star b}$ & 24.86 & $159.00 \pm 3.89^{* \star * b}$ & 17.75 & $31.85 \pm 0.99^{* * \star b}$ & 40.72 & $94.01 \pm 4.81^{* * * b}$ & 36.70 & $31.80 \pm 0.77^{* * \star b}$ & 17.75 \\
\hline (ZSC-3) & 500 & $126.00 \pm 2.42^{* * \star b}$ & 39.95 & $136.66 \pm 3.21^{\star \star \star b}$ & 29.31 & $44.45 \pm 4.65^{\star * \star \mathrm{b}}$ & 96.39 & $54.21 \pm 4.40^{* * * b}$ & 63.49 & $27.33 \pm 0.64^{* * \star b}$ & 29.31 \\
\hline Group VI & 250 & $209.33 \pm 4.85^{\mathfrak{b}}$ & - & $195.33 \pm 3.95^{\mathfrak{D}}$ & - & $23.98 \pm 0.73^{\mathfrak{b}}$ & 5.96 & $146.28 \pm 4.01^{\mathrm{D}}$ & & $39.06 \pm 0.79^{b}$ & \\
\hline (ZSC-4) & 500 & $193.836 \pm 7.08^{\mathrm{D}}$ & 7.62 & $187.50 \pm 5.45^{\mathfrak{b}}$ & 3.10 & $29.30 \pm 0.87^{* \star \star \mathrm{D}}$ & 29.45 & $127.03 \pm 8.2^{* \mathrm{~b}}$ & 14.47 & $37.50 \pm 1.09^{\mathfrak{b}}$ & 3.01 \\
\hline
\end{tabular}

Gp, Group; All values represent mean \pm SEM; ${ }^{\star} p<0.05 ;{ }^{\star *} p<0.01,{ }^{\star * *} p<0.001$; ANOVA, followed by Dunnett's multiple comparison test; ${ }^{a}$ compared with normal group; ${ }^{b}$ compared with diabetic group 
Table 5: Effect of extract on body weight in STZ-induced diabetic mice

\begin{tabular}{|c|c|c|c|c|}
\hline Group & $\begin{array}{l}\text { Dose } \\
(\mathrm{mg} / \mathrm{kg})\end{array}$ & $\begin{array}{l}\text { day } 0 \text { (before treatment) } \\
\text { (mean } \pm S E \text { ) }\end{array}$ & $\begin{array}{c}15 \text { Days (post-treatment) } \\
\text { (mean } \pm \text { SE) }\end{array}$ & $\%$ Change \\
\hline Normal (Saline) & & $20.90 \pm 0.64$ & $24.63 \pm 0.30^{\star \star \star}$ & 17.86 \\
\hline Group I (Diabetic) & & $22.36 \pm 0.58$ & $19.96 \pm 0.55^{\star * *}$ & $24.14 \downarrow$ \\
\hline $\begin{array}{l}\text { Group II } \\
\text { (Glibenclamide) }\end{array}$ & 5 & $22.00 \pm 0.40$ & $26.55 \pm 0.36^{\star * *}$ & $20.68 \uparrow$ \\
\hline Group III (ZSC-1) & $\begin{array}{l}250 \\
500\end{array}$ & $\begin{array}{l}22.40 \pm 0.39 \\
22.60 \pm 0.28\end{array}$ & $\begin{array}{l}20.45 \pm 0.73^{\star} \\
20.88 \pm 0.46^{*}\end{array}$ & $\begin{array}{l}8.70 \downarrow \\
7.59 \downarrow\end{array}$ \\
\hline Group IV (ZSC-2) & $\begin{array}{l}250 \\
500\end{array}$ & $\begin{array}{l}22.95 \pm 0.73 \\
22.05 \pm 0.50\end{array}$ & $\begin{array}{c}24.70 \pm 0.25^{\star} \\
24.61 \pm 0.22^{\star \star \star}\end{array}$ & $\begin{array}{c}7.62 \uparrow \\
11.64 \uparrow\end{array}$ \\
\hline Group V (ZSC-3) & $\begin{array}{l}250 \\
500 \\
250\end{array}$ & $\begin{array}{l}21.11 \pm 0.43 \\
20.93 \pm 0.34 \\
20.81 \pm 0.58\end{array}$ & $\begin{array}{c}24.58 \pm 0.28^{\star * *} \\
25.13 \pm 0.23^{\star * *} \\
19.06 \pm 0.53\end{array}$ & $\begin{array}{c}16.41 \uparrow \\
20.06 \uparrow \\
8.40 \downarrow\end{array}$ \\
\hline Group VI (ZSC-4) & 500 & $22.50 \pm 0.31$ & $17.66 \pm 0.56^{\star * *}$ & $21.48 \downarrow$ \\
\hline
\end{tabular}

All values represent mean $\pm \mathrm{SEM} ;{ }^{*} p<0.05 ;{ }^{* * *} p<0.001$; ANOVA, followed by Dunnett's multiple comparison test

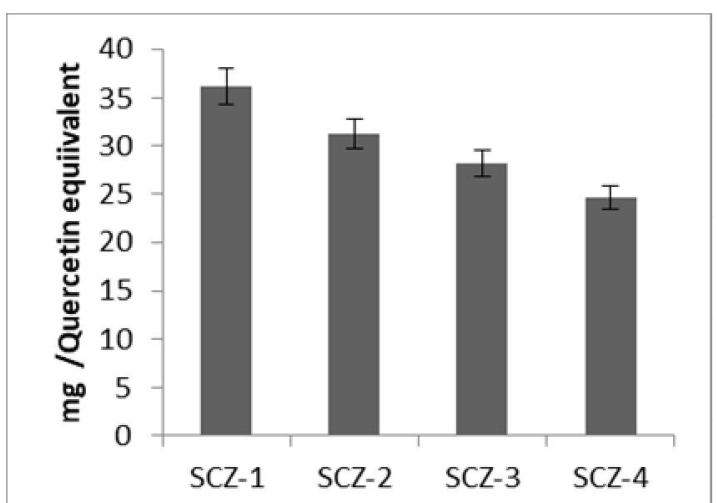

Figure 1: Total flavonoid content of the total extract and different fractions of Ziziphus spina-christi

\section{Total polyphenolic content}

The total phenolic contents of $Z$. spina-christi were measured by the Folin-Ciocalteu assay of Singleton et al [16] and Shahat et al [13] and reported as mgGallic Acid equivalents (GAE) per $\mathrm{g}$ of sample. As shown in Figure 2, the total extract, ZSC-1, had the highest phenolic content $(82.3 \mathrm{mg} / \mathrm{g})$, followed by ZSC-2, ZSC-3, and ZSC-4 at 76.3, 73.6, and $68.3 \mathrm{mg} / \mathrm{g}$ respectively. ZSC-4 had the lowest total phenol content.

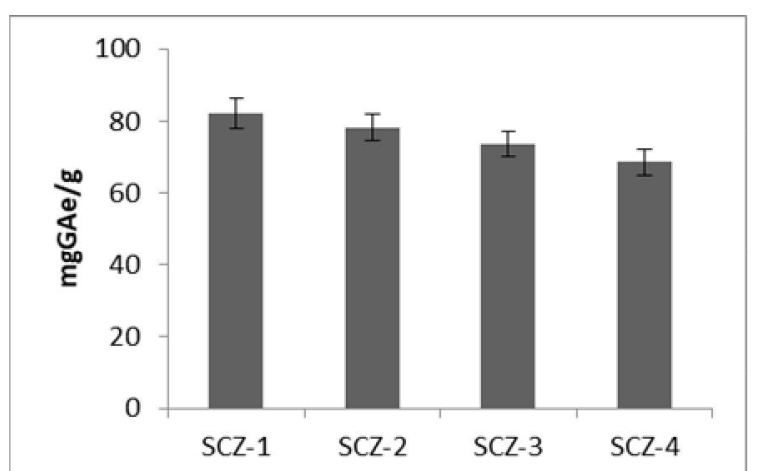

Figure 2: Polyphenolic content of total extract and different fractions of Ziziphus spina-christi

\section{Antioxidant activity}

Antioxidant has been used widely in food industry to prolong the shelf life. Antioxidant term refers to a compound that can be inhibited or delay the oxidation of biomolecules. A numerous number of plant extracts have been investigated for their antioxidant activities [13,17]. The secondary metabolite compounds of the higher plants have been verified in in vitro experiments to defend against oxidative damage through reduction or inhibition of the free radicals and oxygen reactive species.

\section{DPPH radical scavenging activity}

Five concentrations of the tested samples were used with the positive control; the activities were increased as the concentration increases. The total extract (ZSC-1) and the fractions ZSC-2, ZSC-3, and ZSC-4 exhibited strong antiradical activity by reducing the radical stable DPPH to yellow colored (Figure 3 ) in comparison with the positive control (BHA) which is a known antioxidant. The Ethyl acetate fraction (ZSC-2) exhibited higher DPPH scavenging activity (96 $\%)$ compared with the standard, ZSC-3 and ZSC4. ZSC-4 fraction showed lowest activity at 100 $\mu \mathrm{g} / \mathrm{mL}$. A concomitant Increase in scavenging activity with an increase in concentration. The hydrophobic DPPH free radical change in scavenging capacity of the extract and different fraction of Zizyphus spina-christi is shown in Figure 3.

\section{Total antioxidant capacity}

The blue and green ABTS radical cation was generated before the addition of the antioxidant and the degree of radical cation decolorization can be used to measure the relative antioxidant ability of extract compared to that of BHA, The 


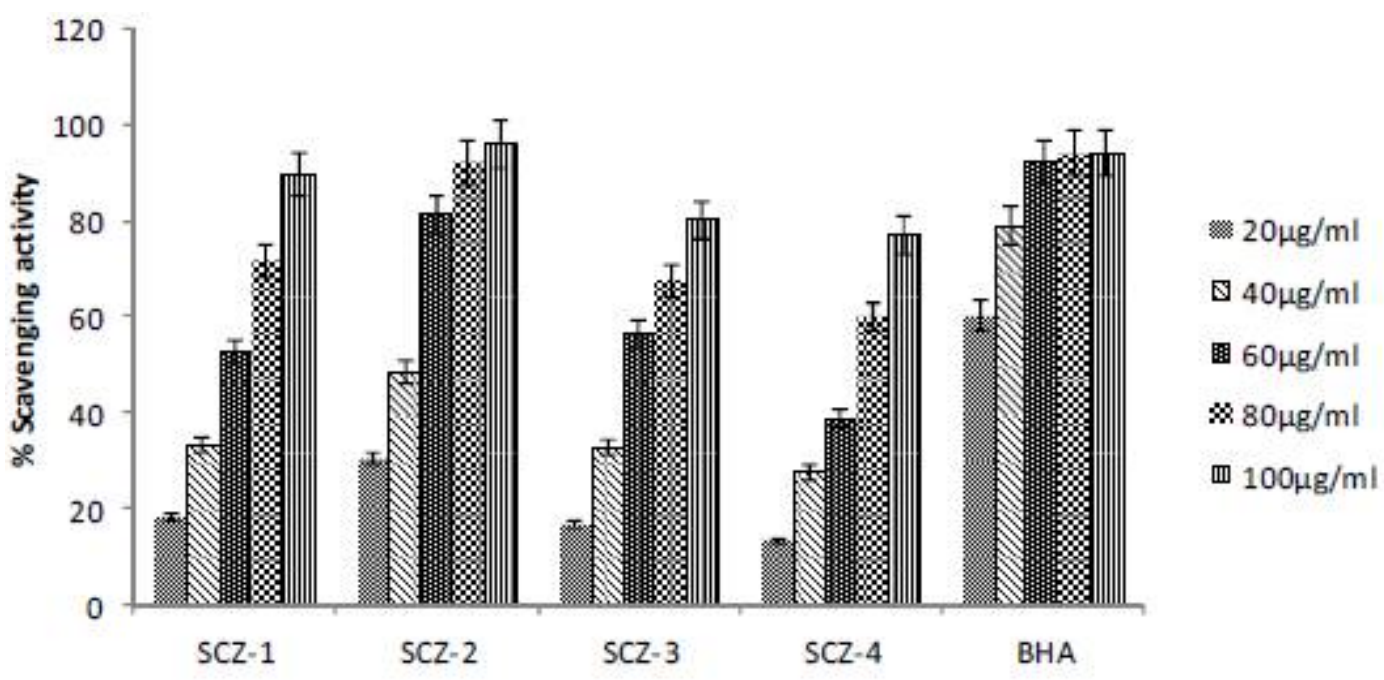

Figure 3: Free radical scavenging activity (DPPH) of ZSC-1 and the different fractions (ZSC-2, ZSC-3, and ZSC4) of Ziziphus spina-christi at different concentrations

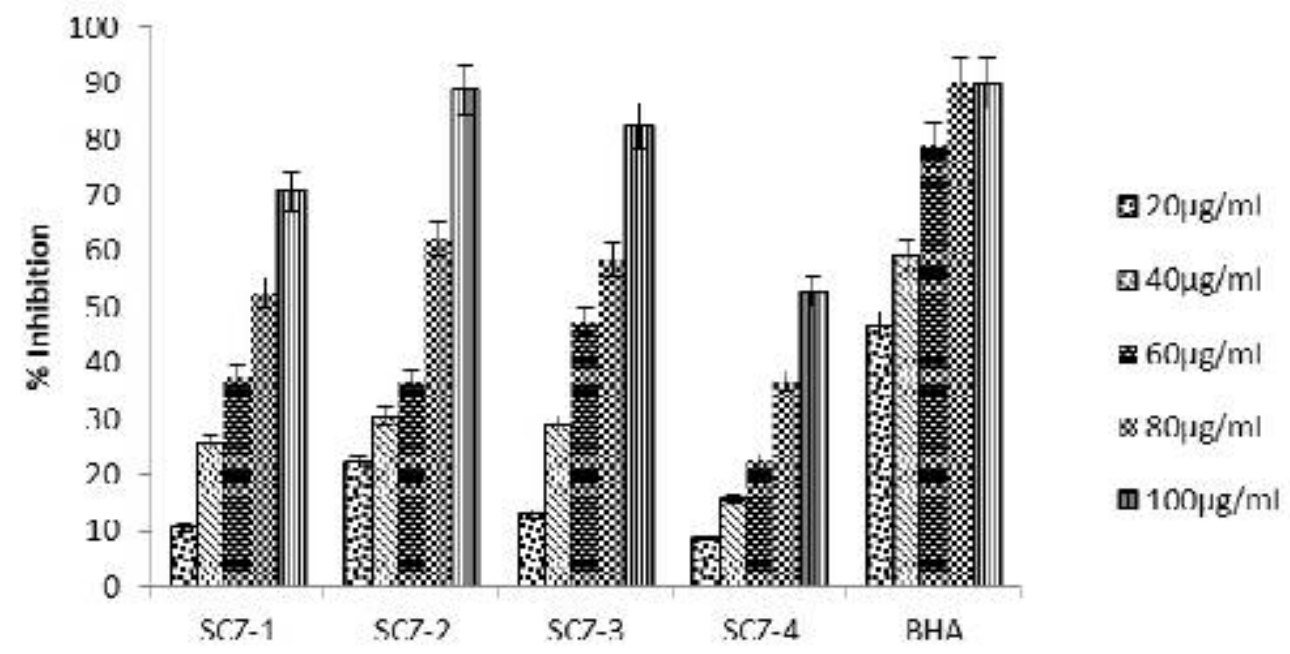

Figure 4: Radical-scavenging activity of extract and fractions from Ziziphus spina-christi at different concentrations

total antioxidant capacity of total extract and different fractions of Zizyphus spina christi at different concentration, measured by using the ABTS, is shown in Figure 4. A concentrationdependent increase in scavenging was observed. ZSC-4 showed lowest ABTS scavenging activity. The total antioxidant activities of ZSC-1, ZSC-2, ZSC-3 and ZSC-4 result in 70.5 to $91.2 \%$ inhibition in the ABTS.

\section{DISCUSSION}

Streptozotocin-induced hyperglycemia has been described as a useful model to study the activity of hypoglycemic agents. Streptozotocin selectively destroys the pancreatic $\beta$ cells, reduce their activity, and cause diabetes [18]. In the present study, significant weight loss was observed in the diabetic group in addition to an improvement in the weight of rats in the diabetic group treated with fraction ZSC-3. This may be a result of the ability of the extracts to reduce hyperglycemia in STZ induced diabetes, which is characterized by severe body weight loss, owing to the loss or degradation of structural protein [19].

In the present study, blood glucose levels were four times higher than the initial level after the induction of diabetes. However, treatment with ZSC-3 fraction reduced blood sugar level compared with levels of the control. The ZSC-3 fraction was more effective in controlling the blood glucose level than the other tested samples. This activity may be attributable to the presence of saponins glycosides [5]. Many studies have shown the blood glucose-lowering effect of plant extracts such as Boehmeria rugulosa [20], and have sought to evaluate the hypoglycemic effect in STZ- and alloxan-induced diabetes mellitus. Hyperlipidemia is a recognized complication of diabetes mellitus, characterized 
by elevated levels of cholesterol, triglycerides and changes in lipoprotein composition.

In the present study, significant hyperlipidemia was observed in STZ-induced rats compared to the normal groups. However, administration of the fractions reduced the hyperlipidemia. ZSC-3 was found to be the most effective, followed by ZSC-2 which indicated that these fractions had the potential to improve insulin secretion. Similarly, many authors have also noticed hypercholesterol and hypertriglycerides condition [21], which supported the data in the present study. The total flavonoids content and polyphenol contents of ZSC-1, ZSC-2, ZSC-3 and ZSC-4 were 36.2, 31.2, 28.2 and $24.6 \mathrm{mg} / \mathrm{g}$ and $76.3 \mathrm{mg} / 1 \mathrm{~g}, 73.6 \mathrm{mg} / 1 \mathrm{~g}$ and $68.3 \mathrm{mg} / 1 \mathrm{~g}$ respectively. The ethyl acetate (SZC-2) fraction showed DPPH scavenging activity greater than the standard compound (96\%); the activities of ZSC-1, ZSC-3 and ZSC-4 were 89, 80.3 and $77.3 \%$, respectively. The total antioxidant activities of ZSC-1, ZSC-2, ZSC-3 and ZSC-4 result were between 70.5 and $91.2 \%$ inhibition in ABTS test.

\section{CONCLUSION}

Fraction ZSC-3 showed potential hypoglycemic activity in diabetic mice. ZSC is rich in flavonoids and polyphenols, which may be responsible for its strong antioxidant effect. Further studies are required to determine the mechanisms of these effects.

\section{DECLARATIONS}

\section{Acknowledgement}

This study was supported by the Deanship of Scientific Research (DSR), King Abdulaziz University, Jeddah (grant no. D-033-363-1437). The authors gratefully acknowledge this support.

\section{Conflict of Interest}

No conflict of interest associated with this work.

\section{Contribution of Authors}

The authors declare that this work was done by the authors named in this article and all liabilities pertaining to claims relating to the content of this article will be borne by them.

\section{Open Access}

This is an Open Access article that uses a funding model which does not charge readers or their institutions for access and distributed under the terms of the Creative Commons Attribution License (http://creativecommons.org/licenses/by/ 4.0) and the Budapest Open Access Initiative (http://www.budapestopenaccessinitiative.org/rea d), which permit unrestricted use, distribution, and reproduction in any medium, provided the original work is properly credited.

\section{REFERENCES}

1. Malviya $N$, Jain $S$, Malviya $S$. Antidiabetic potential of medicinal plants. Acta Pol Pharm AbdEl-Sala NM, Riaz Ullah. In Vitro Antimicrobial Bioassays, DPPH Radical Scavenging Activity, and FTIR Spectroscopy Analysis of Heliotropium bacciferum. Biomed Res Int 2016; 2016: 112.

2. Shahat AA, Pieters L, Apers S, Nazeif NM, Abdel-Azim $N$, Vanden Bergh $D$, Vlietinck AJ. Chemical and biological investigation of Zizyphus spina-cristi. Phytother Res 2001; 15: 593-597.

3. Abdel-Zaher AO, Salim SY, Assaf MH, Abdel-Hady RH. Antidiabetic activity and toxicity of Zizyphus spina-christi leaves. J Ethnopharmacol.2005; 101: 129-138.

4. Niamat $R$, Khan MA, Khan $K Y$, Ahmed M, Mazari $P$, Ali $B$, Mustafa $M$, Zafar $M$. A review on Zizyphus as antidiabetic J App Pharmacol Science 2012; 02 (03): 177-179

5. Adzu B, Amos S, Amizan MB, Gamaniel K. Evaluation of the antidiarrheal effects of Zizyphus spina-christi stem bark in rats. Acta Tropica. 2003; 7: 245-250.

6. Seyuum A, Asres K, El-Fiky FK. Structure radical scavenging activity relationships of flavonoids. Phytochemistry. 2006; 67: 2058-2070.

7. NIH Guide for the Care and Use of Laboratory Animals. Revised (1985). NIH Publication Number. 85-23, U.S. Department of Health, Education and Welfare. Research Triangle Park, North Carolina.

8. Srinivasan K, Viswanad B, Asrat L, Kaul CL, Ramarao P. Combination of high-fat diet-fed and low-dose streptozotocin-treated rat: a model for type 2 diabetes and pharmacological screening. Pharmacol. Res 2005; 52: 313-320.

9. El Tahir KA. Guide to drug discovery: Directions for pharmacological screening for new synthetic and natural compounds leading to discovery of new medicines. Riyadh, El Tahir Publication, 2007; 100-105.

10. Hemant $P$, Sharma $S$, Khajja BS, Jain $K$, Jain GC. Evaluation of hypoglycemic and antihyperglycemic potential of Tridax procumbens Linn. BMC Complement Altern Med. 2009; 9: 48.

11. Zhang $H$, Li X, Wu K, Wang M, Liu P, Wang $X$, Deng $R$. Antioxidant activities and chemical constituents of flavonoids from the flower of Paeonia ostia. Molecules. 2017; 22: 5.

12. Shahat AA, Ibrahim AY, Alsaid MS. Polyphenolic Content and Antioxidant Activity of Some Wild Asteraceae Plants Asian Pac J Trop Med 2014; 7 (7): 554-551.

Trop J Pharm Res, November 2017; 16(11): 2609 
13. Khlifi $S H$, Ben Jemaa $H$, Ben $H$ mad $H$, Abaza $H$, Karmous I. Abid A, Benzarti A, Elati J, Aouidet A. Antioxidant, antidiabetic and antihyperlipidemic effects of Trigonella foenum-graecum seeds. Int. J. Pharmacol. 2016; 12: 394-400.

14. Shahat AA, Ibrahim AY, Alsaid MS. Antioxidant capacity and polyphenolic content of seven Saudi Arabian medicinal herbs traditionally used in Saudi Arabia Indian J_Tradit_Know 2015; 1 (1): 28-35

15. Singleton VL, Orthofer R, Lamuela-Raventos RM, Analysis of total phenols and other oxidation substrates and antioxidants by means of Folin Ciocalteu reagent. Methods Enzymol. 1999; 299: 152-178.

16. Shahat AA, Nazif NM, Abousetta $L M$, Ibrahim NA, Cos $P$, Van Miert S, Pieters L, Vlietinck AJ, Phytochemical investigation and antioxidant activity of Duranta repens. Phytother. Res. 2005; 19: 1071-1073.
17. Szkudelski T. The mechanism of alloxan and streptozotocin action in $B$ cells of the rat pancreas. Physiol Res 2001; 50:536-546

18. Veeramani $C$, Pushpavalli G, Pugalendi $K V$. In vivo antioxidant and hypolipidemic effect of Cardiospermum halicacabum leaf extract in streptozotocin-induced diabetic rats. J. Basic Clin. Physiol. Pharmacol., 2010; 21(2): 107-125

19. Semwal DK, Rawat $U$, Semwal $R$, Singh $R$, Krishan $P$, Singh $M$, Singh $G$. Chemical constituents from the leaves of Boehmeria rugulosa with antidiabetic and antimicrobial activities. J Asian Nat Prod Res 2010; 11: 1045-1055

20. Venkatesh S, Dayanand RG, Madhava $R$. Antihyperglycemic and hypolipidemic effects of Helicteres isora roots in alloxan induced diabetic rats Pharmaceut Biol 2010; 5: 347-350 